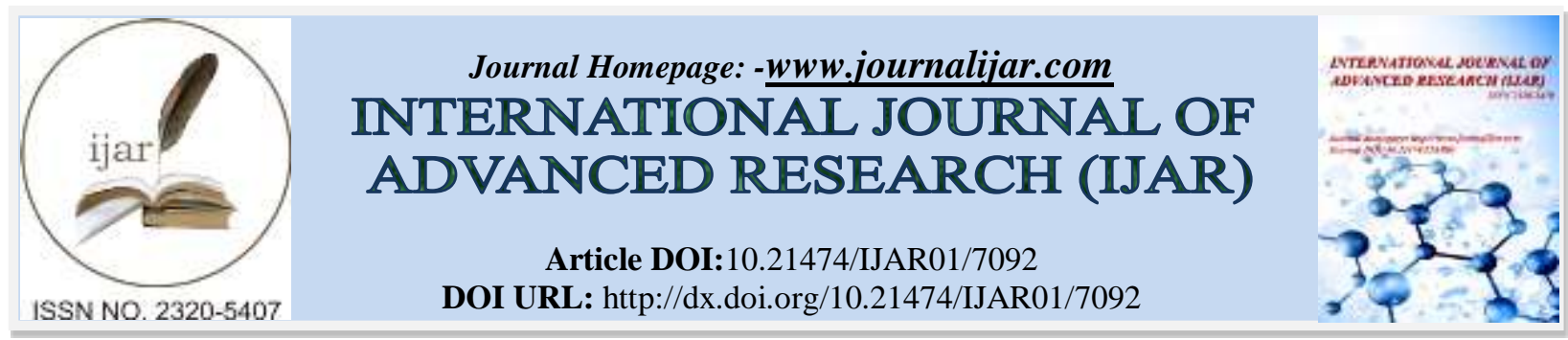

RESEARCH ARTICLE

\title{
THE EFFECT OF COMPENSATION, COMPETENCE, AND TALENT MANAGEMENT ON EMPLOYEES PERFORMANCE OF THE IKATAN MOTOR INDONESIA.
}

\author{
Dr. Ignatius Jeffrey ${ }^{1}$ and Wenty Febrianti ${ }^{2}$. \\ 1. Lecture of Management of Postgraduate, University of Mercu Buana, Jakarta, Indonesia. \\ 2. Master of Management, University of Mercu Buana, Jakarta, Indonesia.
}

\section{Manuscript Info}

Manuscript History

Received: 13 March 2018

Final Accepted: 15 April 2018

Published: May 2018

Keywords:-

compensation, competence, talent management, employee performance.

\begin{abstract}
As a facilitator of the sports industry, Ikatan Motor Indonesia (IMI) should be supported by qualified resources so that the human resource management technique can be run properly and correctly. Based on primary and secondary data can be focused three dominant factors that influence employee performance of the Ikatan Motor Indonesia i.e. (1) Compensation, (2) Competence, (3) Talent Management. The sampling method used was the probability sampling. The research involved the population of 85 employees, while the sample size of 70 employees was determined using Slovin's formula. The data were processed using the multiple linear regressions. The results showed that compensation, competence and talent management simultaneously had positive and significant effects on the employee performance of Ikatan Motor Indonesia. Partially, compensation and talent management had positive and significant impacts on the employee performance of Ikatan Motor Indonesia, while competence did not have an effect on the employee performance of Ikatan Motor Indonesia. Compensation was the variable that has the greatest effect on employee performance. Based on the results of the research, it is expected that the management of Ikatan Motor Indonesia can pay attention to the compensation, competence and talent management so that the employee performance will increase.
\end{abstract}

Copy Right, IJAR, 2018,. All rights reserved.

\section{Introduction:-}

Every organization or company should pay attention to the existing human resources by properly and correctly implementing the techniques of human resource management. Ikatan Motor Indonesia (IMI) acts as an organization that facilitates the automotive sports industry throughout the provinces, together with the government to integrate and to cooperate in the fields of tourism, social sector and automotive industry, as a facilitator and for smooth activities as well as in order to provide good services for all provinces, the Ikatan Motor Indonesia must be supported by qualified resources. However, in the last three years, the employees of Ikatan Motor Indonesia experienced a decline in their performance. Reports on the decrease in the employee performance of Ikatan Motor Indonesia can be seen from the decrease in the employee attendance reports and from the employee appraisal reports. 
Table 1:-Employee Attendance Reports of Ikatan Motor Indonesia of 2015-2017

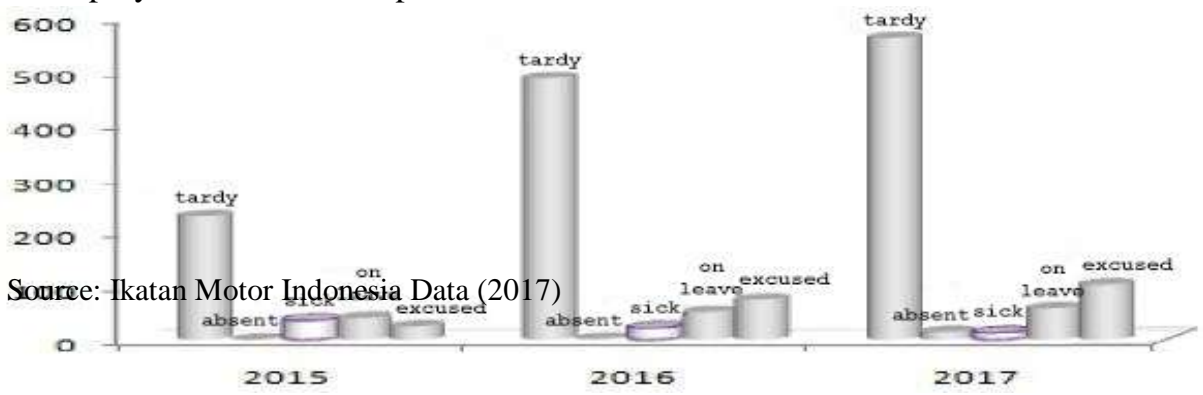

Table 2:-Summary of the Employee Performance Appraisal Values of Ikatan Motor Indonesia

\begin{tabular}{|l|l|l|}
\hline Year & Number of Employees & Average Value \\
\hline 2015 & 118 & 3.2 \\
\hline 2016 & 118 & 3 \\
\hline 2017 & 118 & 2.9 \\
\hline
\end{tabular}

Source: Ikatan Motor Indonesia Data (2017)

Based on the results of the pre-research, it is concluded that there are 3 variables which allegedly have effects on the employee performance, i.e. (1) Compensation, (2) Competence, and (3) Talent Management. Therefore, the effect of compensation, competence and talent management on the employee performance of Ikatan Motor Indonesia needs further researches.

\section{Theoretical Review:- \\ Compensation:-}

In the study by Nawiyah et al. (2017:80), Compensation is a function of Human Resource Management (HRM) related to any type of reward which an individual receives in return for the implementation of organizational tasks. The study by Thaief et al. (2015:24) said that employee compensation is any form of payment or allowances granted to employees and results from the employees' works. Riana and Wirasadena (2016:83) said that compensation may be in the form of financial and non-financial. For an organization, compensation reflects the efforts to maintain and improve the welfare of their employees. Hameed et al. (2014:302) suggest that compensation is the output and benefits that employees receive in the form of wages, pays and also the similar rewards as a money exchange for employees to improve the Performance. Njoroge \& Kwasira (2015:90) state that compensation may include expenses such as bonuses, profit sharing, overtime fees and gifts that consist of monetary and non-monetary gifts such as house rental and car facilities for employees.

\section{Competence:-}

Jeffrey and Dinata's research (2017:7302) said that competence is the underlying characteristic of people that shows ways to behave or think, which generalizes in various situations and persists for long periods According to Asumeng (2014:2), competence was first introduced by White in 1959 to describe an individual characteristic where it is specifically said that intelligence or cognitive potential may influence motivation and will, in turn, predict workplace performance . Lotunani et al. (2014:19) conclude that competence is the individual's ability to perform tasks assigned to them. Furthermore, the concept of competence can also be understood as knowledge, skills, and professional identity. Sriekaningsih and Setyadi (2015:209) state that competence is an individual nature associated with the effective implementation of a job. The limits of competence or special competence for a job are the system or guidelines in employee selection (selection of personnel), succession planning, performance appraisal, and development. The research written by Renyut (2017:20) states that competence represents the ability of a person to produce at a satisfactory level in the workplace, shows the characteristics of knowledge and skills possessed or required by each individual that enables them to perform their duties and responsibilities effectively and enhance the quality standards of Professional works.

\section{Talent Management:-}

According to Armstrong (2016:82), Talent management is as a traditional HRM activity such as manpower planning, recruitment, employee retention management, performance management, potential assessment, leadership, management development, succession planning and career planning. According to Sadri et al. (2015:51), talent 
management generally refers to the exploration, discovery, selection, maintenance, development and improvement, or use of manpower restructuring. According to Maya and Thamilselvan (2013:455), talent management is the ability to create and continue to optimize the talent resources needed to run a business strategy. The research of Tash et al. (2016:226) states that talent management is one of the main management tools for managing human assets in the 21st century, since the primary resource for companies to compete is not only land, capital and other physical assets but human capital is also needed by organizations to adapt to global competitions and maximize the benefits associated with the prosperous current technologies. The research by Mangusho et al. (2015:191) says that talent management is the knowledge of using strategic HR to increase business value and enable companies and organizations to achieve their goals. Everything that is done to recruit, maintain, develop, give rewards and get people to do it is part of the Talent Management as well as the strategic manpower planning.

\section{Performance:-}

Jeffrey and Dinata's study (2017:7302) explains that work performance is an important part of human resource management and an important criterion for the outcome and the success of an organization. Meanwhile, according to Jeffrey and Dantes (2017:1451), performance aspects that need to be measured from subordinates are including teamwork quality, creativity in problem-solving, and work discipline. Jeffrey and Soleman's research (2017:107) states that performance management is the process of consolidating goal setting, assessment and performance development into a single shared system, which aims to ensure that the employee performance supports the company's strategic objectives. Jeffrey and Ruliyanto's research (2017:78) said that performance is a set of values of employee behaviors that contribute, positively or negatively, to company goals.

\section{Research Method:- Research Model:-}

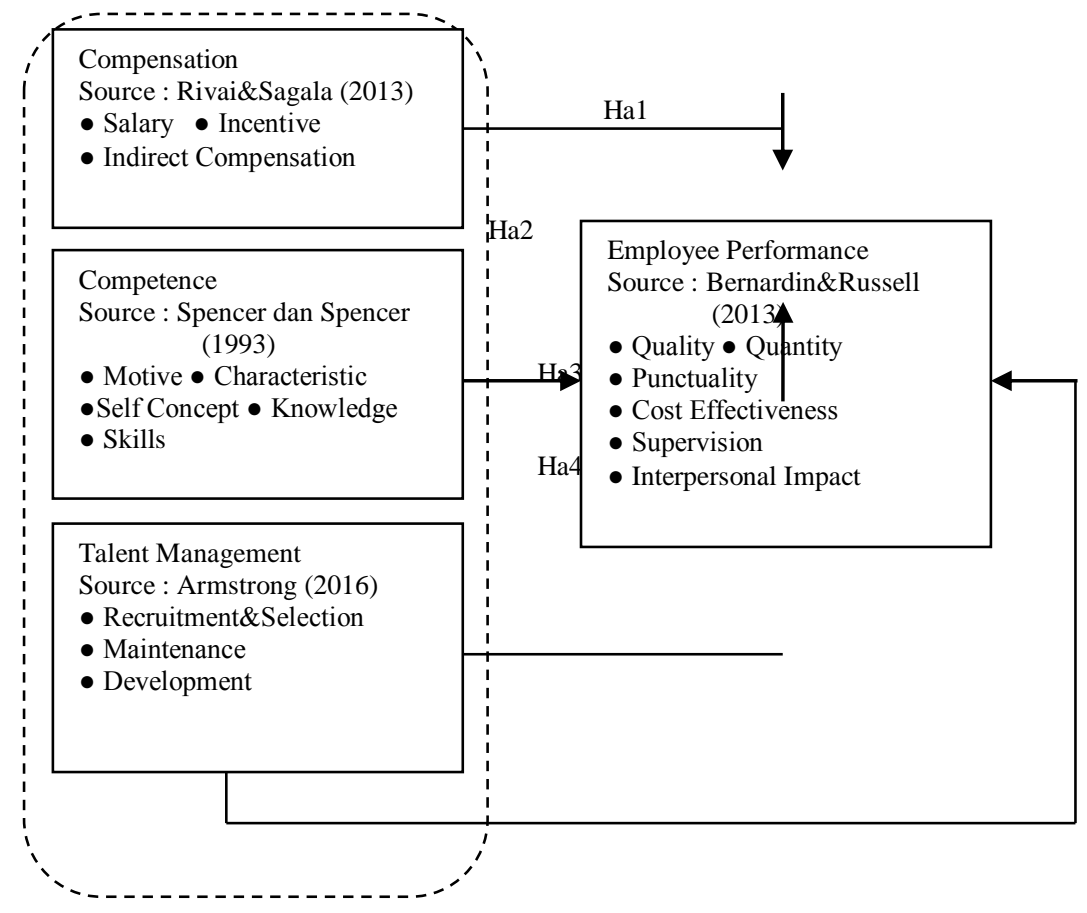

Figure 1:-Research Model

\section{Hypotheses:-}

Based on the results of previous studies and the research model in Figure 1, several hypotheses raised in this study are as follows:

Ha1: Compensation influences the Employee Performance of Ikatan Motor Indonesia.

Ha2: Competence influences the Employee Performance of Ikatan Motor Indonesia.

Ha3: Talent Management influences the Employee Performance of Ikatan Motor Indonesia. 
Ha4: Compensation, Competence, and Talent Management simultaneously influence the Employee Performance of Ikatan Motor Indonesia.

\section{Research Method:-}

This is descriptive research to explain the effect of the models. The population involved 85 people and the sample size was 70 respondents, determined using Slovin'Sto formula. Primary data were collected from questionnaires distributed directly to employees of Ikatan Motor Indonesia. Secondary data were sourced from data of Ikatan Motor Indonesia organization, literature studies through various books, and related journals and articles. Data were processed using multiple regressions. Based on the instrument test using validity and reliability tests, it can be concluded that the questionnaire items submitted were valid and reliable. Hypothesis tests ( $\mathrm{F}$ test and $\mathrm{t}$ test) were done after successfully passed the classical assumption tests, which are normality, multicollinearity, and heteroscedasticity. Calculation of correlation and testing techniques were done with the help of computer using SPSS application version 17.

Operational Variables:-

Table 3:-Operational Variables

\begin{tabular}{|c|c|c|c|c|}
\hline No. & Variable & Dimension & Indicator & Statement Number \\
\hline 1. & $\begin{array}{l}\text { Compensation } \\
\text { (X1) }\end{array}$ & $\begin{array}{l}\text { Theory of Rivai and } \\
\text { Sagala (2013) } \\
\text { a. Salary } \\
\text { b. Incentive } \\
\text { c. Indirect } \\
\text { Compensation }\end{array}$ & $\begin{array}{l}\text { Source: Adaptation from Rivai } \\
\text { and Sagala } \\
\text { 1. Accuracy of salary payments } \\
\text { 2. Compliance of salary with } \\
\text { the prevailing wage structure } \\
\text { and scale } \\
\text { 3. Compliance of salary with } \\
\text { the minimum wage } \\
\text { standards } \\
\text { 4. Salary satisfaction } \\
\text { 1. Good work environment } \\
\text { 2. Overtime } \\
\text { 1. Social Security } \\
\text { 2. Easiness in applying for a } \\
\text { leave }\end{array}$ & $\begin{array}{l}1 \\
2,3 \\
4 \\
5,6,7 \\
8,9 \\
10,11 \\
\\
12,13 \\
14,15\end{array}$ \\
\hline 2. & $\begin{array}{l}\text { Competence } \\
\text { (X2) }\end{array}$ & $\begin{array}{l}\text { Theory of Spencer \& } \\
\text { Spencer (1993) } \\
\text { a. Motive } \\
\text { b. Characteristic } \\
\text { c. Self Concept } \\
\text { d. Knowledge } \\
\text { e. Skills }\end{array}$ & $\begin{array}{l}\text { Source: Adaptation from Spencer } \\
\text { 1. Results-oriented } \\
\text { 1. Initiative } \\
\text { 2. Teamwork and cooperation } \\
\text { 3. Developing others } \\
\text { 1. Confidence } \\
\text { 2. Self-control } \\
\text { 1. Searching for information } \\
\text { 2. Appropriate } \\
\text { Knowledge } \\
\text { 1. Skilled in designing work } \\
\text { 2. Conceptual and analytical } \\
\text { thinking }\end{array}$ & $\begin{array}{l}1,2 \\
3 \\
4 \\
5 \\
6 \\
7 \\
8,9,10 \\
11,12 \\
13 \\
14,15\end{array}$ \\
\hline
\end{tabular}




\begin{tabular}{|c|c|c|c|c|}
\hline 3. & $\begin{array}{l}\text { Talent } \\
\text { Management } \\
\text { (X3) }\end{array}$ & $\begin{array}{l}\text { Theory of Armstrong } \\
\text { (2016) } \\
\text { a. Recruitment- } \\
\text { b. Maintenance } \\
\text { c. Development }\end{array}$ & $\begin{array}{l}\text { Source: Adaptation from } \\
\text { Armstrong } \\
\text { 1. Talented Employee } \\
\text { 2. Talent Mapping } \\
\text { 1. Commitment-based } \\
\text { compensation } \\
\text { 2. Welfare-based compensation } \\
\text { 1. Training } \\
\text { 2. Coaching } \\
\text { 3. Employee development } \\
\text { programs }\end{array}$ & $\begin{array}{l}1 \\
2 \\
3,4,5 \\
6,7,8 \\
\\
9,10 \\
11,12 \\
13,14,15\end{array}$ \\
\hline 4. & $\begin{array}{l}\text { Employee } \\
\text { Performance } \\
\text { (Y) }\end{array}$ & $\begin{array}{l}\text { Theory of Bernardin } \\
\text { and Russel (2013) } \\
\text { a. Quality of Work } \\
\text { b. Quantity of Work } \\
\text { c. Punctuality } \\
\text { d. Cost Effectiveness } \\
\text { e. Supervision Needs } \\
\text { f. Interpersonal }\end{array}$ & $\begin{array}{l}\text { Source: Adaptation from } \\
\text { Bernardin and Russel } \\
\text { 1. Pertinence } \\
\text { 2. Accuracy } \\
\text { 1. The suitability of the number } \\
\text { and capability } \\
\text { 1. Time } \\
\text { 2. The effectiveness of } \\
\text { working hours } \\
\text { 1. Technology } \\
\text { 1. No supervision } \\
\text { 1. Compliance \& Cooperation }\end{array}$ & $\begin{array}{l}1,2 \\
3,4 \\
5,6 \\
7 \\
8,9 \\
10,11 \\
12,13 \\
14,15\end{array}$ \\
\hline
\end{tabular}

Source: Data compiled from various sources

\section{Research Results:-}

Respondents Characteristics:-

The answer results of respondents' characteristics showed that there are 18 respondents (26\%) working as chief secretary, the secretary position consists of 24 respondents (34\%), and staff consists of 28 respondents (40\%). Next, the number of the respondents with 1-year work period is 11 respondents (16\%), with 2-4 years work period is 29 respondents (41\%), with 5-10 years work period is 23 respondents $(33 \%)$, and with $>10$ years work period is 7 respondents $(10 \%)$. Then based on the work location, there are 26 respondents $(37 \%)$ in Sumatra, 31 respondents $(44 \%)$ in Java, and 13 respondents (19\%) in Kalimantan.

Data Analysis;-

\section{Research Instrument Test;-}

The validity test of $X_{1}, X_{2}, X_{3}$, and $Y$ variables on each questionnaire statement showed valid data because the Corrected Item Total Correlation was greater than 0.3 . The reliability test showed that the variable $X_{1}$, regarding compensation with a Cronbach's alpha of 0.804 , is greater than 0.6 and thus can be considered as reliable. Variable $\mathrm{X}_{2}$ on competence with a Cronbach's alpha of 0.898 , is greater than 0.6 and thus can be considered as reliable. Variable $\mathrm{X}_{3}$ of talent management with a Cronbach's alpha equal to 0.878 , is greater than 0.6 and thus can be considered as reliable. Variable Y on performance with a Cronbach's alpha of 0.890 , is greater than 0.6 and thus can be considered as reliable. Therefore, it can be concluded that all of the instruments used were reliable. 


\section{Classical Assumption Test;-}

The results of the classical assumption test showed that the normality test passed because the distribution of errors was still around the straight line and followed the direction of the diagonal line so that the regression model met the assumption of normality. Multicollinearity test results showed that the compensation, competence and talent management variables were not correlated or multicollinearity did not occur in the research model because the VIF value was smaller than 10 . The results of heteroscedasticity test showed that there was no heteroscedasticity as they were seen in the points that spread randomly above and below zero (0) and did not form a certain pattern, hence, it can be said that the regression did not experience heteroscedasticity disturbance so that the regression model could be used feasibly to predict the work performance based on the input of the independent variables.

\section{Regression Analysis:-}

The multiple linear regression analysis showed:

Table 4:-Multiple Regression Test Results

\begin{tabular}{|c|c|c|c|c|c|c|c|}
\hline \multirow[t]{3}{*}{ Model } & \multicolumn{2}{|c|}{ Unstandardized } & \multicolumn{3}{|c|}{ Standardized } & \multicolumn{2}{|c|}{ Collinearity } \\
\hline & \multicolumn{2}{|c|}{ Coefficients } & \multicolumn{3}{|c|}{ Coefficients } & \multicolumn{2}{|c|}{ Statistics } \\
\hline & $\mathrm{B}$ & Std. Eror & Beta & $\mathrm{t}$ & Sig & Tolerance & VIF \\
\hline (Constant) & 8.004 & 4.469 & & 1.791 & .0 .78 & & \\
\hline Compensation (X1) & .402 & .123 & .392 & 3.264 & .002 & .491 & 2.038 \\
\hline Competence (X2) & -.053 & .079 & -.070 & -.662 & .510 & .646 & 1.558 \\
\hline $\begin{array}{l}\text { Talent } \quad \text { Management } \\
\text { (X3) }\end{array}$ & .381 & .101 & .447 & 3.775 & .000 & .505 & 1.979 \\
\hline
\end{tabular}

Source: Processed primary data (2018)

From the above results, the regression equation model can be made as follows:

$Y=8.004+0.402 X_{1}-0.053 X_{2}+0.381 X_{3}$

The multiple regression equation above showed constant value of 8.004 suggesting that if compensation, competence and talent management variables were constant, then the performance of employees of the Ikatan Motor Indonesia was 8.004. The $\mathrm{X}_{1}$ regression coefficient of 0.402 stated that every increase in $\mathrm{X}_{1}$ (compensation increased by $1 \%$ ) then the performance of IMI employees would increase by 0.402 . The $\mathrm{X}_{2}$ regression coefficient was minus 0.053 showing that competence did not have an effect on the employee performance of Ikatan Motor Indonesia. The $\mathrm{X}_{3}$ regression coefficient of 0.381 stated that every increase in $\mathrm{X}_{3}$ (talent management increased by $1 \%$ ) then the employee performance of Ikatan Motor Indonesia will increase by 0.381 .

Hypothesis Test:-

Partial Test (t test):-

Table 5:-t-Test Result

\begin{tabular}{|c|c|c|c|c|c|c|c|}
\hline \multirow[t]{3}{*}{ Model } & \multicolumn{2}{|c|}{ Unstandardized } & \multicolumn{3}{|c|}{ Standardized } & \multicolumn{2}{|c|}{ Collinearity } \\
\hline & \multicolumn{2}{|c|}{ Coefficients } & \multicolumn{3}{|c|}{ Coefficients } & \multicolumn{2}{|c|}{ Statistics } \\
\hline & $\mathrm{B}$ & Std. Eror & Beta & $\mathrm{t}$ & Sig & Tolerance & VIF \\
\hline (Constant) & 8.004 & 4.469 & & 1.791 & .0 .78 & & \\
\hline Compensation (X1) & .402 & .123 & .392 & 3.264 & .002 & .491 & 2.038 \\
\hline Competence (X2) & -.053 & .079 & -.070 & -.662 & .510 & .646 & 1.558 \\
\hline $\begin{array}{l}\text { Talent } \quad \text { Management } \\
\text { (X3) }\end{array}$ & .381 & .101 & .447 & 3.775 & .000 & .505 & 1.979 \\
\hline
\end{tabular}

Source: Processed primary data (2018)

Based on the results of the above table, it can be explained as follows:

The first hypothesis: The effect of compensation on the employee performance:-

Ho: Compensation did not have significant effect on the employee performance

Ha: Compensation had significant effect on employee performance

Table 5 shows that the value of $t_{\text {count }}$ is 3.264 and $t_{\text {table }}$ is 1.9955 , thus the value of $t_{\text {count }}$ is greater than the value of $\mathrm{t}_{\text {table }}$ and its significance value of 0.002 is less than 0.025 , thus it can be concluded that Ha is accepted and Ho is rejected, which means that the compensation variable has positive and significant effect on the employee performance variable. 
The second hypothesis: The effect of competence on the employee performance:-

Ho: Competence did not have significant effect on the employee performance

Ha: Competence had significant effect on employee performance

Table 5 shows that the value of $\mathrm{t}_{\text {count }}$ is minus 0.662 and $\mathrm{t}_{\text {table }}$ is 1.9955 , thus the value of $\mathrm{t}_{\text {count }}$ is smaller than the value of $\mathrm{t}_{\text {table }}$ and its significance value of 0.510 is more than 0.025 , so it can be concluded that $\mathrm{Ha}$ is rejected and Ho is accepted, which means that the competence variable did not have significant effect on the employee performance variable.

The third hypothesis: The effect of talent management on the employee performance:-

Ho: Talent management did not have significant effect on the employee performance

Ha: Talent management had significant effect on employee performance

Table 5 shows that the value of $t_{\text {count }}$ is 3.775 and $t_{\text {table }}$ is 1.9955 , thus the value of $t_{\text {count }}$ is greater than the value of $\mathrm{t}_{\text {table }}$ and its significance value of 0.000 is less than 0.025 , so it can be concluded that Ha is accepted and Ho is rejected, which means there is a positive and significant effect of the talent management variable on the employee performance variable.

\section{Simultaneous Test (F Test):-}

F test results were used to test whether independent variables simultaneously affected the dependent variable. Basic decision-making was made based on the value of significance, if the $\mathrm{F}_{\text {count }}$ is greater than $\mathrm{F}_{\text {table }}$ or significantly smaller than the error rate of $5 \%$ (sig. <0.05) then Ho is rejected. The hypothesis is presented as follows:

$\mathrm{Ho}=$ Compensation, competence and talent management simultaneously did not have significant effect on employee performance.

$\mathrm{Ha}=$ Compensation, competence and talent management simultaneously had significant effect on employee performance.

The results of the hypothesis from the F test can be seen in the following table:

Table 6:-F Test Results

\begin{tabular}{|l|l|l|l|l|l|l|}
\hline Model & & Sum of Squares & Df & Mean Square & F & Sig. \\
\hline 1 & Regression & 1137.698 & 3 & 379.233 & 25.006 & $.000^{\mathrm{a}}$ \\
\hline & Residual & 1000.945 & 66 & 15.166 & & \\
\hline & Total & 2138.643 & 69 & & & \\
\hline
\end{tabular}

Source: Processed primary data (2018)

Based on Table 6 above, the results of simultaneous hypothesis test or $\mathrm{F}$ test showed the $\mathrm{F}_{\text {count }}$ value of 25.006 and $F_{\text {table }}$ value of 2.7437, thus the value of $F_{\text {count }}$ is greater than $F_{\text {table }}$ value and its significance value of 0.000 is less than 0.05 . Hence, Ho is rejected and $\mathrm{Ha}$ is accepted. This concludes that the variables of compensation, competence and talent management simultaneously had significant and positive effect on the employee performance.

\section{Coefficient of Determination}

Table 7:-Coefficient of Determination Result

\begin{tabular}{|l|l|l|l|l|}
\hline Model & R & R Square & Adjusted R Square & Std. Error of the Estimate \\
\hline 1 & $.729^{\mathrm{a}}$ & .532 & .511 & 3.894 \\
\hline
\end{tabular}

Source: Processed primary data (2018)

The simultaneous correlation value based on table 7 was $\mathrm{R}$ of 0.729 , this number describes that the the compensation, competence and talent management variables simultaneously were correlated positively and significantly with the employee performance. With the value of $\mathrm{R}=0.729$ in accordance with the interpretation table of the correlation coefficient, the simultaneous effect of compensation, competence, and talent management variables on the employee performance was strong. The value of $\mathrm{r}^{2}$ (R Square) is 0.532 . This means that $53.2 \%$ of employee performance is influenced by the compensation, competence, and talent management variables and the remaining $46.8 \%$ is caused by other variables beyond the research model. 


\section{Discussion And Analysis:-}

Compensation affects employee performance:-

Based on the results of t test analysis, partially, compensation has a positive and significant effect on the employee performance of Ikatan Motor Indonesia, suggesting that if the compensation increases then the employee performance will increase. This finding is in line with previous research results by Nawiyah et al. (2017) stating that compensation has a positive and significant impact on employee performance, Hameed et al. (2014) in his study found that compensation has a positive influence on employee performance, Blazovich (2013) found in his research that compensation has a positive effect on employee performance, the study of Riana et al. (2016) found that compensation has a positive and significant influence on employee performance, then Thaief et al. (2015) and Aslam et al. (2015) stated that compensation has a positive effect on employee performance. Therefore, the management of Ikatan Motor Indonesia must pay attention to the compensation given to the employees, the compensation has to be provided in accordance with the provisions of the applicable Laws of Labor and carried out fairly so as to provide welfare for the employees. If the employee welfare has been met, the employee morale will increase thereby it can lead to improvement in their performance, and this finding is in accordance with the research conducted by Riana and Wirasadena (2016:83) which states that for an organization, compensation reflects the efforts to maintain and improve the welfare of their employees.

\section{Competence affects employee performance:-}

Based on the results of t test analysis, partially, competence does not affect the employee performance of Ikatan Motor Indonesia, it means that if there is an increase in competence then there is no increase in employee performance. This is contrary to Murgianto's research (2016) which found that competence has a significant influence, Suyitno's research (2017) found that competence has a positive and significant effect on employee performance, then Arifin (2013) who stated in his research that competence has a positive effect on employee performance. Competence does not affect the performance of employees because, in the Ikatan Motor Indonesia, there are still some employees in certain positions who are not supported by an education in accordance with the type of work, therefore the application of competence to a position has not been done optimally.

\section{Talent Management affects employee performance:-}

The results of t test showed that partially, talent management has a positive and significant impact on the employee performance of Ikatan Motor Indonesia. This means that if talent management is improved, employee performance will increase. This hypothesis result supports the study by Eghbal et al. (2017) which stated that talent management has a positive effect on employee performance, Mensah (2015) in his research found that talent management has a positive effect on employee performance, then Febriani (2012) and Mangusho et al. (2015) also stated that talent management has a positive effect on employee performance. Therefore, the application of talent management at the Ikatan Motor Indonesia needs to be considered, especially in the implementation of recruitment and selection of employees because recruitment and selection represent the first step in getting talented employees. With the application of good talent management, it means that the management of Ikatan Motor Indonesia has been paying attention to the career growth and the development of the organization through talents owned by the employees so that they can directly affect the employee performance.

\section{Compensation, competence, and talent management affect employee performance:-}

Based on the results of $F$ test analysis, the compensation, competence, and talent management simultaneously affect the performance of the employees of Ikatan Motor Indonesia, thus it can be interpreted as if there is an increase in compensation, competence and talent management, they will simultaneously improve the employee performance of Ikatan Motor Indonesia. Therefore, these three variables must be taken into account by the organization of Ikatan Motor Indonesia in order to improve their employee performance.

\section{Conclusion And Suggestion:- \\ Conclusion:-}

Based on the analysis results in this study, it can be concluded that:

1. Compensation, competence and talent management variables simultaneously have a significant influence on the employee performance variable.

2. Variable compensation has a positive and significant effect on the employee performance variable.

3. Variable competence has no effect and no significance to the employee performance variable.

4. Variable talent management has a positive and significant effect on the employee performance variable. 


\section{Suggestion:-}

1. The results of this study proved that compensation, competence and talent management simultaneously have an influence on employee performance, it is expected that the management of Ikatan Motor Indonesia considers these three variables in an effort to improve the employee performance.

2. To improve the compensation, it is suggested that the management pay more attention to the salary structure in order to provide compensation to employees, which is done fairly and equitably.

3. To improve the existing talent management implementation, it is suggested that the management pay more attention to the recruitment and selection activities of employees by performing talent mapping. Then, for the development of employees, it is suggested that the management consider implementing training for employees. With the training need analysis, the training given is on target and can increase the employee competence that can lead to promotions.

4. For the next research, it is suggested to carry out a study by using other variables as the factors that can affect employee performance, which have not been used in this study.

5. For the next research, it is suggested to carry out a study in any province which has not been investigated in this research.

6. For the next research, it is suggested to perform a study by using data collected in the period of 2018 , as well as performing data processing using other applications other than SPSS, such as Structural Equation Modeling (SEM) or Partial Least Square (PLS).

\section{References:-}

1. Arifin, H. Muhammad. (2013). "The Influence of Competence and External Motivation Factor toward Teachers Working Performance in Jayapura - Papua Indonesia”. IOSR Journal of Business and Management (IOSR$J B M)$, Vol.7, No,5, pp.1-7.

2. Armstorng, Michael. (2016). Armstrong's Handbook of Management and Leadership for HR: Developing Effective People Skills For Better Leadership and Management. Kogan Page Limited. Philadelphia.

3. Aslam, Ayesha., Amna Ghaffar., Tahleel Talha., dan Hina Mushtaq. (2015). "Impact of Compensation and Reward System on The Performance of an Organization: an Empirical Study on Banking Sector of Pakistan". European Journal of Business and Social Sciences, Vol.4, No,8, pp.319-325.

4. Asumeng, Maxwell. (2014). "Managerial Competency Models: A Critical Review and Proposed Holistic-Domain Model". Macrothink Institute, Vol.6, No,4, pp.1-21.

5. Bernardin and Russel. (2013). Human Resource management: An. Experimential Approach. McGraw-Hill. New York.

6. Blazovich, Janell L. (2013). "Team Identity and Performance-Based Compensation Effects on Performance". Team Performance Management, Vol.19, No,3/4, pp.153-184.

7. Eghbal, Farzaneh., Reza Hoveida., Seyed Ali Siadat Seyadat., Hossein Samavatyan., dan Mohammad Hossein Yarmohammadian. (2017). "The Effect of Talent Management Process on the Research Performance of Faculty Members with the Mediating Role of Organizational Justice". Foresight And Sti Governance, Vol 2, No,2, pp.83-92.

8. Hameed, Abdul., Muhammad Ramzan., Hafiz M. Kashif Zubair., Ghazanfar Ali., dan Muhammad Arslan. (2014). "Impact of Compensation on Employee Performance (Empirical Evidence from Banking Sector of Pakistan)". International Journal of Business and Social Science. Vol.5, No,1, pp.1-19.

9. Jeffrey, Ignatius dan Mahmud Soleman. (2017). "The Effect of Work Discipline, Achievement Motivation and Career Path Toward Employee Performance of The National Resilience Institute of The Republic of Indonesia". International Journal of Application or Innovation in Engineering \& Management (IJAIEM), Vol.6, No,8, pp.106-113.

10. dan Marta Herdian Dinata. (2017). "The Effect of Work Motivation, Work Discipline, and Competence on Employee Performance”. International Journal of Current Advanced Research. Vol.6, No,11, pp.7301-7307.

11. dan Reisza Vallewey Dantes. (2017). "The Effect of Leadership, Work Motivation, Work Environment Toward Employees Performance". International Journal of Advanced Research (IJAR). Vol.5, No,8, pp.1450-1458.

12. dan Ruliyanto. (2017). "The Effect of Competence, Training and Work Discipline towards Employees' Performance (A Case Study at PT. Krakatau Argo Logistics)”. International Journal of Business and Management Invention. Vol. 6, No,7, pp.77-86.

13. Lotunani, Alamsyah., M.S Idrus., Eka Afnan., dan Margono Setiawan. (2014). "The Effect of Competence on Commitment, Performance and Satisfaction with Reward as a Moderating Variable (A Study on Designing 
Work plans in Kendari City Government, Southeast Sulawesi)". International Journal of Business and Management Invention, Vol.3, No,2, pp.18-25.

14. M, Maya dan R. Thamilselvan. (2013). "Impact of Talent Management on Employee Performance and Organisational Efficiency in ITSPS-With Reference to Chennai City". IJER, Vol.10, No,2, pp.453-461.

15. Mangusho, Yona Sakaja., Raphael Kipkoech Murei., dan Eunice Nelima. (2015). "Evaluation of Talent Management on Employees Performance in Beverage Industry: A Case of Delmonte Kenya Limited". International Journal of Humanities and Social Science, Vol.5, No,8, pp.192-205.

16. Mensah, James Kwame. (2015). "A "Coalesced Framework" of Talent Management and Employee performance". International Journal of Productivity and Performance Management, Vol.64, No,4, pp.544566.

17. Murgianto., Siti Sulasmi., dan Suhermin. (2016). "The Effects of Commitment, Competence, Work Satisfaction on Motivation, and Performance of Employees at Integrated Service Office of East Java”. International Journal of Advanced Research, Vol.3, No,378, pp. 378-396.

18. Nawiyah., Ignatius Jeffrey., dan Prioyono. (2017). “The Effect of Compensation and Motivation toward Employee Performance of The Academy of Company Leadership of Jakarta". Tepak Journal of Business Management, Vol.IX, No,2, pp. 75-95.

19. Njoroge, Sheila Wambui dan Josephat Kwasira. (2015). "Influence of Compensation and Reward on Performance of Employees at Nakuru County Government". IOSR Journal of Business and Management, Vol.17, No,11, pp.87-93.

20. Renyut, Bernard C., H. Basri Modding., Jobhar Bima., dan St. Sukmawati. (2017). "The Effect of Organizational Commitment, Competence on Job Satisfaction and Employees Performance in Maluku Governor's Office”. IOSR Journal of Business and Management, Vol.19, No,11, pp.18-29.

21. Riana , I Gede., Wayan Pradnyantha Wirasedana. (2016). "The Effect of Compensation on Organisational Commitment and Employee Performance with the Labour Union as the Moderating Variable". Scientific Journal of PPI-UKM. 3:2356-2536, Vol.3, No,2, pp. 2356-2536.

22. Rivai, Veithzal and Ella Jauvani Sagala. (2013). Human Resource Management for The Company. Edition 2nd. PT. Raja Grafindo Persada. Jakarta.

23. Sadri, Ali., Hesam Pirouz., Shadi Sharifi., dan Mehdi Farhadi. (2015). "Studying the Impact of Talent Management on Performance of Staffs". International Academic Journal of Economics. Vol.2, No,11, pp.50-59.

24. Spencer, Lyle M. and Signe M. Spencer. (1993). Competence Work: Model for Superior Performance. John Wiley and Sons. Inc. Canada.

25. Sriekaningsih, Ana. (2015). "The Effect of Competence and Motivation and Cultural Organization towards Organizational Commitment and Performance on State University Lecturers in East Kalimantan Indonesia". European Journal of Business and Management, Vol.7, No,17, pp.208-219

26. Suyitno. (2017). "Effect of Competence, Satisfaction and Discipline on Performance of Employees in the Office of Women Empowerment and Family Planning of West Papua”. Canadian Center of Science and Education", Vol.13, No,5, pp.144-152.

27. Thaief, Ilham., Aris Baharuddin., Priyono., dan Mohamad Syafi'i Idrus. (2015). "Effect of Training, Compensation and Work Discipline against Employee Job Performance”. Review of European Studies, Vol.7, No,11, pp.24-33.

28. Tash, Mohim Sheihaki., Elham Nowrouzi Cheshmeh Ali., dan Maryam Ahmadzadeh. (2016). "The Effects of Talent Management on Employees Performance in Oil Jam Petrochemical Complex (Oil JPC): The Mediating Role of Job Satisfaction”. International Journal of Economics and Finance, Vol. 8, No,6, pp.226230 . 